\title{
Nick Dyer-Witheford and Greig de Peuter, Games of Empire: Global Capitalism and Video Games (2009)
}

Ian Reyes

University of Rhode Island

Follow this and additional works at: https://digitalcommons.uri.edu/mgdr

Part of the Anthropology Commons, Communication Commons, Economics Commons, International Business Commons, Marketing Commons, Other Business Commons, and the Sociology Commons

\section{Recommended Citation}

Reyes, Ian (2017) "Nick Dyer-Witheford and Greig de Peuter, Games of Empire: Global Capitalism and Video Games (2009)," Markets, Globalization \& Development Review: Vol. 2: No. 1, Article 8.

DOI: 10.23860/MGDR-2017-02-01-08

Available at: https://digitalcommons.uri.edu/mgdr/vol2/iss1/8

This Book Review is brought to you for free and open access by DigitalCommons@URI. It has been accepted for inclusion in Markets, Globalization \& Development Review by an authorized editor of DigitalCommons@URI. For more information, please contact digitalcommons-group@uri.edu. 
Nick Dyer-Witheford and Greig de Peuter, Games of Empire: Global Capitalism and Video Games (2009)

\section{Markets, Globalization \& Development Review}
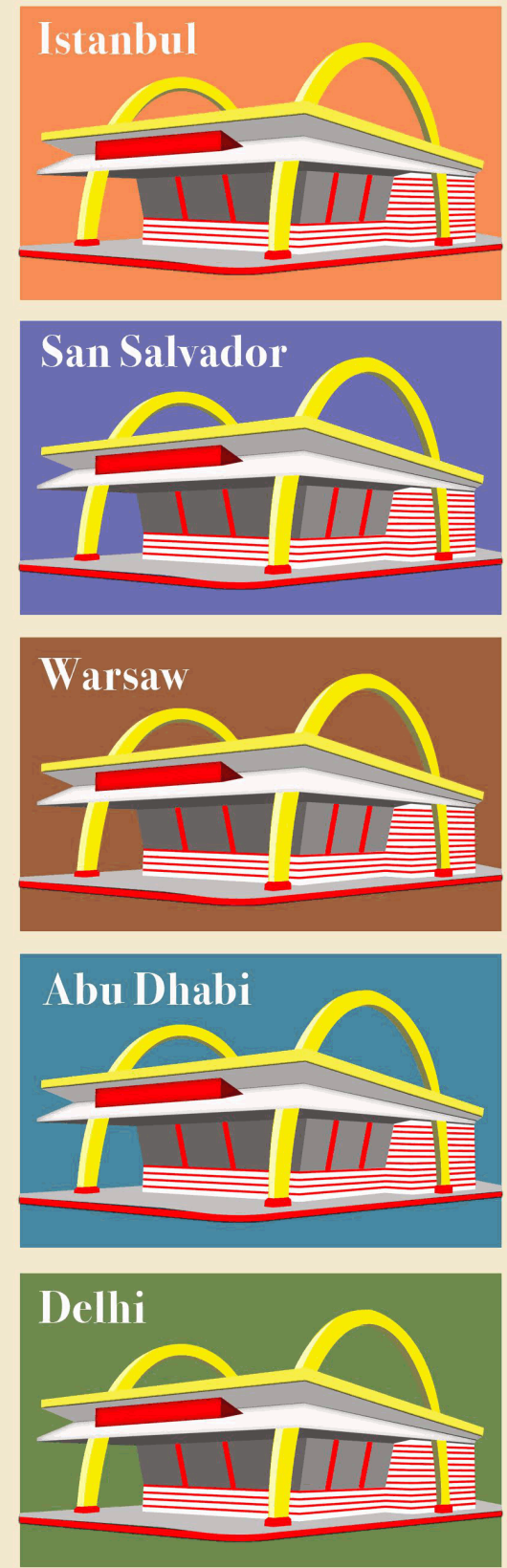

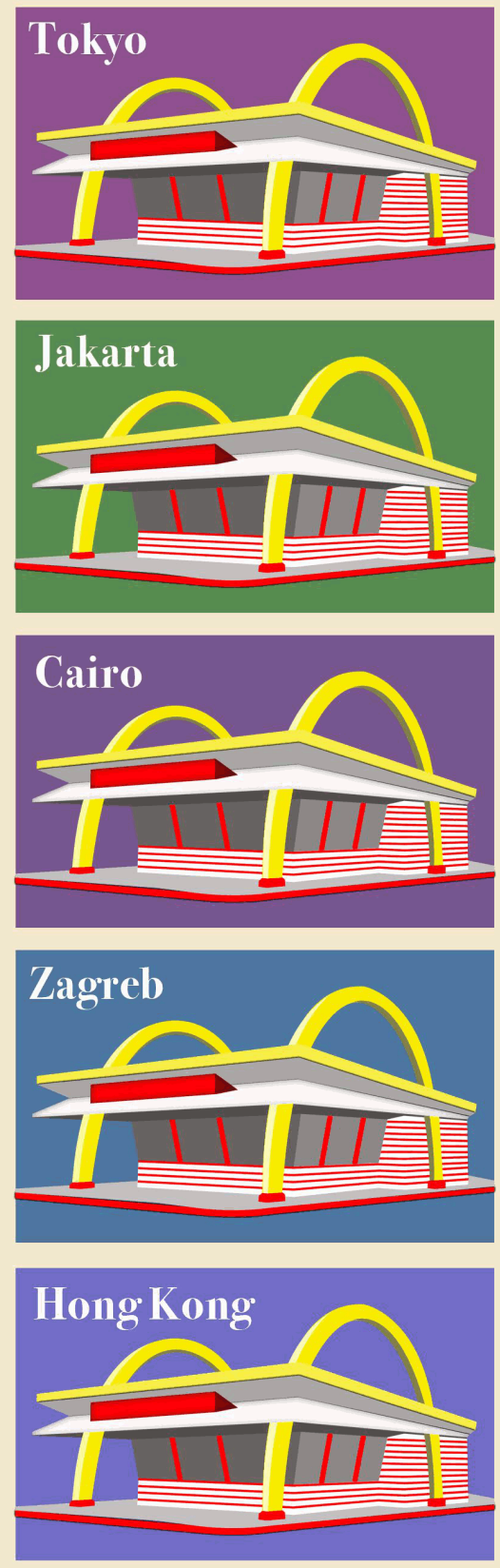

This book review is available in Markets, Globalization \& Development Review: https://digitalcommons.uri.edu/mgdr/ vol2/iss $1 / 8$ 


\section{Book Review}

\section{Nick Dyer-Witheford and Greig de Peuter, Games of Empire: Global Capitalism and Video Games (2009)}

In Games of Empire: Global Capitalism and Video Games (2009), Nick Dyer-Witheford and Greig de Peuter integrate industry analysis, content analysis, and critical theory in ways both familiar and provocative thanks to the authors' explicitly politicized take on these topics. Games of Empire is positioned to be different from both the negative, media effects tradition of game studies as well as the more recent, celebratory work on video games and their players. For instance, Dyer-Witheford and de Peuter's take on video game violence cuts across the usual worries about imitative violence or defenses of catharsis, and instead seeks to show that video games, as an industry as well as a set of mediated representations, have always been inextricable from the technologies, tactics, and ideologies of the military industrial complex.

Divided into three main sections - "Game Engine: Labor, Capital, Machine," "Gameplay: Virtual/Actual," and "New Game?" - the book evaluates the role of video games in the creation and perpetuation of "Empire."

By Empire, we mean the global capitalist ascendancy of the early twenty-first century, a system administered and policed by a consortium of competitively collaborative neoliberal states, among whom the United States still clings, by virtue of its military might, to an increasingly dubious preeminence. This is a regime of biopower based on corporate exploitation of myriad types of labor, paid and unpaid, for the continuous enrichment of a planetary plutocracy. (Dyer-Wtheford and de Peuter 2009, p. xxiii [original emphasis])

Thus, this is not about classic imperialism supporting a particular empire (e.g., the British empire). It is about about a certain, hegemonic stage of global history where networks of power transcend the bounds of modernity. This concept is built upon Michael Hardt and Antonio Negri's initial theorization in Empire (2000), where they argue: "Empire is emerging today as the center that supports the globalization of productive networks and casts its widely inclusive net to try to envelop all power relations within its world order - and yet at the same time it deploys a powerful police function against the new barbarians the rebellious slaves 
who threaten its order" (p. 20). Dyer-Witheford and de Peuter take special interest in these new barbarians and rebellious slaves, members of what Hardt and Negri call "the multitude," who offer both resistance and fuel to Empire. They are "productive, creative subjectivities of globalization that have learned to sail on this enormous sea. They are in perpetual motion and they form constellations of singularities and events that impose continual global reconfigurations of the system" (Hardt and Negri 2000, p. $60)$. The driving force of this book is to ask how "the multitude" are subjugated by Empire via video games, and whether this same system might be turned by the multitude to strike back against Empire, forging alternatives to global capital.

On one level, Games of Empire is a critical account of the evolution of the global video game industry, detailing issues of labor, management, and consumption shaping this evolution. It is a welcome alternative to more typical, deterministic accounts of video game history, which gloss innovation and development in video game markets as an apolitical matter of technological "progress." Here, instead, the authors show how video game evolution is governed more by capitalistic rather than technological or ludological measures of progress. The development of online, multiplayer games, for example, figures in Games of Empire as a strategy to exploit play-time, extending the game market beyond merely selling hardware and software; the impetus for this innovation was neither the drive to improve the technology as such nor to satisfy new consumer desires, rather it was part and parcel of broader trends in late capitalism to incorporate ever more territory so that nothing remains outside its reach, not even private moments of play and pleasure.

The other aim of Games of Empire is to illustrate and evaluate Hardt and Negri's Empire (2000). Dyer-Witheford and de Peuter describe Hardt and Negri's book as "an experimental fusion of Marxist militancy and poststructuralist theory" (p. xxi). Extending Empire's sensibilities certainly lends Games of Empire a distinct flavor, and some of the digressions into the finer points of post-Marxist theory and politics may be lost on readers unconcerned with the nuances of Hardt and Negri's vision. Nonetheless, even if one has not yet engaged the original Empire, its essential propositions deployed by Dyer-Witheford and de Peuter should be recognizable to anyone reasonably familiar with $20^{\text {th }}$ century social theory. The notion that there is a historical stage of development with "no outside," no stable ground for democratic resistance to the totalizing forces of capital and its modes of being and thinking, is recapitulated time and again by post-Marxist theorists, who appear throughout the book as friends or foils to Hardt and Negri's perspective. 
Through this approach, Dyer-Witheford and de Peuter offer some insightful updates to well-trod terrain in this branch of theory, insights not limited to video games specifically. These include a critique of social power in the business of producing cyborg bodies, and explaining interactive spectacle as inspiration for the voluntary production of surplus value essential to new media economies. To be sure, the argument that interactivity has not proven to be the panacea that social critics of old, mass media had hoped is a unifying theme of this book. Whereas the old, $20^{\text {th }}$ century problematic was the passivity of the masses in the face of monolithic, unidirectional, mass media communications, the new, $21^{\text {st }}$ century problematic comes from what, initially, seemed to be the answer to audience passivity and mass media oligarchy. Combining the interactivity of video gaming with the connectivity of internet-based communications holds the promise of enhanced, more autonomous political agency, but Dyer-Witheford and de Peuter show that the material conditions for that promise have, so far, done more to allow the tendrils of global capital to multiply and penetrate into previously untouchable nooks and crannies of everyday life; new media, including but not limited to video games, thus magnify rather than mitigate old media problems.

So, too, does this book offer fresh looks at well-trod terrain in game industry analyses. Considering, for example, the custom for commentary on video game marketing to point out that video gaming is one of the fastest-growing sectors of the entertainment industry, outpacing even Hollywood, Dyer-Witheford and de Peuter parse the hype and challenge fuzzy, misleading categorizations. They argue that game markets are not entirely comparable to film markets, which have more ancillary revenue streams, and, furthermore, video games are part of those streams. Gaming is largely symbiotic with old media industries, therefore growth in this sector does not necessarily come at the expense of others; it may in fact speak to the adaptability and vitality of firms in connected sectors. Games of Empire shows how video games are integral to global markets, even beyond the traditional bounds of the entertainment industry; it also goes a step further, examining the socio-political contexts and implications for this growth.

The two levels of the book, industry-oriented and theory-oriented, come together most powerfully in the closing section concerning the political valence of games, gaming, and gamer cultures for resisting and overturning the seemingly inexorable spread of Empire. Readers of MGDR would do well to read this book alongside Romeo V. Turcan's (2016) commentary on the many senses of "lateness" in globalization and development. One finds in Games of Empire an account of video games 
as quintessential "late" media in that they participate in, indeed are amalgamated with, a "mature" form of capitalism. Moreover, there are consequences for those only lately coming to the threshold of Empire.

On this note, one of the most sobering threads of this theorization of the industry concerns globalizing value chains and divisions of labor for video games, whereby lately developed nation states (e.g., BRIC countries) are implicated at a number of points ranging from mineral extraction to hardware manufacturing to software programming to E-waste dumping, truly spanning the entire life cycle of a video game. In the big picture painted by Games of Empire, one will see how culturally and politically distinct sensibilities from a few dominant regions define the video game imaginary, and that this global dominance is built on the backs of populations marginalized by the ideologies and economies of the very products and services they provide. So, what is to be done?

Drawing to a conclusion, the authors ask, "[i]f the Pentagon and Wall Street can use virtual worlds to plan the Empire, why should communards not use them to think through their escape routes?" (p. 206). If games of Empire are the problem, "games of multitude" are the solution. And just as games of Empire derive power from diverse yet connected spheres of influence - including modes of production, game content, and cultures of play - so, too, do games of multitude. Dyer-Witheford and de Peuter's six-point plan for multitudinous development is: "[c]ounterplay, dissonant development, tactical games, polity simulators, self-organized words, and software commons" (p. 211). Each strategic point is explained and articulated with the others; in practical terms, solutions run the gamut from clever Situationist détournement to good, old-fashioned seizing the means of production.

For better or worse, the post-structural theory motivating this radical, Marxist perspective on video games also provides much of the logic and structure for the book. Written largely in a "rhizomatic" style (cf. Deleuze \& Guattari), the evidence and argumentation of Games of Empire, while unified by coherent and consistent philosophical and political sensibilities, move from one critical topos to another, sometimes jumping quickly between subjects as varied as observations about routinizing overtime, a list of games with "empire" in the title, and arguments about gender representations. Nonetheless, to say that they do not proceed linearly (because the phenomenon they analyze is, itself, nonlinear and rhizomatic) is not to say that they are needlessly obtuse. Taking the book on the whole, readers will find here a great churning of resistance and incorporation across multiple, interconnected spheres, an exposition that convincingly illustrates what it means for there to be 
nothing outside of Empire. So convincing, however, that it may be hard for readers to feel as optimistic as the authors seem to be for the future of counter-hegemonic strategies.

Published in 2009, today's reader will surely wonder how the perspectives presented in Games of Empire might be extended or revised based on developments in the years since. Technology has changed, the industry has changed, and international politics have changed. Still, while there are, arguably, major differences between video games then and now, these differences seem to align with the tendencies Dyer-Witheford and de Peuter describe.

The surge of smartphones and mobile gaming since 2009 is, of course, a major change that makes video games more ubiquitous while also spreading new commercial paradigms, including free-to-play and micro-transactional schemes that define contemporary mobile markets. The competition between iOS and Android platforms is obviously reminiscent of the "console wars" of the " $80 \mathrm{~s}$ and "90s. The major difference, however, is that smartphones are more convergent and more personal devices; thanks to more "casual" styles of play and technical features like geolocation and in-app purchases, smartphone games are designed to occupy and monetize spaces and times that old game media could not touch. Surely, new types of game play intended to yoke consumers to the cart of global capital even in their most fleeting moments of free time squares perfectly with the observations in Games of Empire.

While smartphone gaming is part of a greater consolidation of global capital, it is also part of growing diversity in game design owing to the relative openness of online, digital distribution compared to the old, more exclusionary ages of cartridges and discs. Even more open than the digital marketplaces for mobiles and consoles are online marketplaces like Steam and Humble Store, where independent game developers enjoy distribution on par with the biggest firms. Breaking down barriers between players and independent designers has also been furthered by crowdfunding new games. By far the biggest independent success story since 2009 has been Minecraft. Originally the work of a lone, indie designer from Sweden, it became one of the most popular games in the world; today it is owned by Microsoft and its brand has spread beyond video games to include a dizzying array of Minecraft merchandise.

So popular is Minecraft today, the generation of children growing up after Millenials has been referred to as the "Minecraft generation" (Thompson 2016). This is significant not only because it shows how a global giant, like Microsoft, feeds off of independent successes, something Dyer-Witheford and de Peuter find throughout video game history. It is 
significant also because Minecraft is an unusual type of game concerned as much or more with creativity and collaboration than violent competition; it is an environment for all sorts of play. That, taken alongside its fansupported, independent origins, makes Minecraft a potentially fruitful example of a game of multitude. The fact that it is a touchstone for an entire generation might bode well for the future.

Indeed, it seems, as Dyer-Witheford and de Peuter predict, that improved funding and distribution for smaller developers would open channels for different types of games and play - thus different types of politics - and this is not limited to mega-successes like Minecraft. More recent, independent, and explicitly anti-Empire games including Papers, Please - in which players perform the job of an immigration officer deciding who to can become a citizen - and the This War of Mine series - wherein players experience life as non-combatant civilians trying to survive an urban warzone, playing as victims rather than perpetrators of the violence depicted in more hegemonic war games. These fit nicely with the kinds of games and gaming experiences praised by Games of Empire.

In this same moment, however, the rise of E-Sports-organized, competitive video-gaming leagues-shows a countervailing trend. What were once local, amateur, player-organized competitions have become global, corporate-sponsored, professional competitions (Taylor 2015). Led by the popularity of team-oriented games like League of Legends (Riot Games) and Starcraft (Blizzard Entertainment), the potential for video games to become the next big spectator sport is drawing investment from media/tech firms, like Microsoft and TenCent, as well as other sectors, including MasterCard and Coca Cola (Gaudiosi 2016). Competition to define and control E-Sports involves everything from efforts to design games intended for competition, to founding leagues for competition, to funding players and teams, to building digital platforms for hosting competitions, and securing streaming/broadcasting agreements for events. So, while multitudinous Minecrafters are poised as new barbarians and rebellious slaves at the gates of Empire, new ramparts are being erected and defended with new imperial strategies like E-Sports.

As hopeful as some signs may be, the principles of Empire and the history of video games Dyer-Witheford and de Peuter present suggest that the pendulum should be expected to swing the other way, that the multitude may have its moments but the economic and political tides are not in its favor. Nevertheless, the implications of global turning points, including Brexit and a Trump presidency, may stir the global economy in unexpected ways. Whatever the outcomes, examining the recent past in light of the arguments and insights of Games of Empire shows that this 
book should help readers critically examine the industry's past as well as to guide them forward as the global gaming scene continues to evolve. 


\section{References}

Deleuze, G. and F. Guattari (2003), A Thousand Plateaus: Capitalism and Schizophrenia. B. Massumi (trans). New York, NY: Continuum.

Dyer-Witheford, N. and G. de Peuter (2009), Games of Empire: Global Capitalism and Video Games. University of Minnesota Press.

Gaudiosi, J. (2016), "These are the Most Popular Games on Twitch", Forbes. April 6, 2016, (accessed March 2017), [available at http://fortune.com/2016/04/06/most-popular-esports-games-ontwitch/]

Hardt, M. and A. Negri (2000), Empire. Cambridge, MA: Harvard University Press.

Taylor, T. L. (2015), Raising the Stakes: E-Sports and the Professionalization of Computer Gaming. Cambridge, MA: MIT Press.

Thompson, C. (2016), "The Minecraft Generation", New York Times, (accessed January 2017), [available at http://www.nytimes.com/2016/04/17/magazine/the-minecraftgeneration.html? $\mathrm{r}=0$ ]

Turcan, R. V. (2016), "Exploring Late Globalization: A Viewpoint", Markets, Globalization \& Development Review, 1 (2), (accessed January 2017), [available at http://digitalcommons.uri.edu/mgdr/vol1/iss2/4] 